\title{
ANALYSIS OF DIFFICULTIES IN LEARNING MATHEMATICS IN ELEMENTARY SCHOOL
}

\author{
Gamar Al Haddar ${ }^{1)}$, Eliza Novianti ${ }^{2)}$ \\ ${ }^{1)}$ Program Studi Pendidikan Guru Sekolah Dasar, FKIP, Universitas Widya Gama Mahakam, Indonesia \\ Jl. KH.Wahid HasyimNo 28 RT 007 Kota Samarinda, Provinsi Kalimantan Timur \\ 2) Program Studi Pendidikan Guru Sekolah Dasar, FKIP, Universitas Widya Gama Mahakam, Indonesia \\ Jl. KH.Wahid Hasyim no 28 RT 007 Kota Samarinda, Provinsi Kalimantan Timur \\ *EmailPenulis Korespondensi: gamar_haddar@yahoo.co.id, elizanovianti2106@gmail.com
}

\begin{abstract}
Mathematics is a way to solve problems in daily life so that it is necessary to be mastered. However most of students still believe that mathematics is difficult lesson to learn. Relating to this issue, the researcher conducted a qualitative research to describe the difficulties encountered by students when learning Mathematics. To collect the data, the researcher applied observation, interview, and documentation. The data was then analyzed through data reduction, data display and conclusion.

Having analyzed the data, it can be concluded that students' difficulties in learning Mathematics came from teacher's techniques in explaining the lesson, inadequate school's facilities and infrastructure, family environment, and curriculum. Hence, it is suggested to teachers to apply teaching techniques based on theory of mathematics learning, and enriched with learning aids to encourage students' motivation and positive attitude. In addition, the parents are expected to pay more attention to students' learning development especially on learning difficulties of learning mathematics by cooperating with the teachers.
\end{abstract}

Key words: Difficulties in Learning Mathematics

\section{Pendahuluan}

Pendidikan mempunyai peranan yang sangat penting dalam mewujudkan sumber daya manusia yang tangguh menghadapi perkembangan dan modernisasi kehidupan. Melalui pendidikan peserta didik dapat menemukan pengetahuan yang dapat dikembangkan menurut kompetensi individu masing-masing. Oleh karena itu, pendidikan hendaknya dapat menyiapkan peserta didik menjadi anggota masyarakat yang memiliki kemampuan akademik dan profesional dalam bidang tertentu. Pendidikan dapat menjamin kelangsungan hidup manusia yang cerdas dan sejahtera. Pencapaian standar proses untuk meningkatkan kualitas pendidikan dimulai dari menganalisa setiap komponen yang dapat membentuk serta mempengaruhi proses pembelajaran.

Pendidikan akan terus menjadi salah satu topik pembicaraan yang menarik. Menarik karena dalam pembukaan UUD 1945 tercantum salah satu tujuan pendidikan nasional bangsa Indonesia mencerdaskan kehidupan bangsa untuk mencapai tujuan pendidikan nasional tersebut diselenggarakan upaya pembangunan yang berkesinambungan, menyeluruh dan terpadu. Pembangunan nasional dibidang pendidikan merupakan salah satu upaya demi mencerdaskan kehidupan bangsa dan meningkatkan kualitas manusia Indonesia dalam mewujudkan masyarakat yang maju, adil, dan makmur berdasar pancasila dan UndangUndang Dasar 1945 yang memungkinkan warganya mengembangkan diri sebagai manusia Indonesia seutuhnya.

Pada dasarnya kesulitan belajar siswa didasari bukan hanya pada kematangan mental tetapi pada prestasi atau kemampuan pencapaian prestasi yang saat ini. Sekolah dasar adalah tempat atau wadah bagi anak untuk belajar yang dibimbing oleh para guru yang dimana proses belajarnya dimulai dari anak-anak yang berumur 6-7 tahun untuk bisa mendaftar 
masuk Sekolah Dasar. Hal ini dikarenakan pendidikan memiliki peran yang sangat signifikan dan bahkan masih menjadi pranata utama dalam menyiapkan sumber daya manusia.

Pada saat ini sering kita temui anak-anak yang mengalami kesulitan belajar. Pada dasarnya kesulitan belajar tidak hanya dialami oleh siswa yang berkemampuan rendah saja, tetapi juga dialami oleh siswa yang berkemampuan tinggi. Selain itu kesulitan belajar dapat dialami oleh siswa yang berkemampuan rata-rata disebabkan oleh faktor-faktor tertentu yang menghambat tercapainya kinerja akademik sesuai harapan.

Guru dalam proses pembelajaran memegang peran yang sangat penting, peran guru apalagi untuk siswa pada usia pendidikan sekolah dasar tidak mungkin dapat digantikan oleh perangkat lain seperti televisi, radio, komputer dan lain sebagainya sebab siswa adalah organisme yang sedang berkembang yang memerlukan bimbingan dan bantuan orang dewasa.

Mengajar merupakan istilah kunci yang hampir tak pernah luput dari pembahasan mengenai pendidikan karena keeratan hubungan antara keduanya. Sebagian orang menganggap mengajar hanya sedikit bagian dari pendidikan. Mengajar hanya dianggap sebagai salah satu alat atau cara dalam menyelenggarakan pendidikan, bukan pendidikan itu sendiri.

Guru Dalam menjalankan tugasnya sebagai penyaji pelajaran khususnya di kelas, tidak hanya dituntut mentransfer pengetahuan atau isi pelajaran yang ia sajikan kepada para siswanya melainkan lebih daripada itu. Mengajar adalah membimbing serta memudahkan siswa dalam menjalani proses perubahannya sendiri, yakni proses belajar demi meraih kecakapan cipta, rasa, dan karsa yang menyeluruh dan utuh. Sudah tentu kecakapankecakapan seluruh ranah psikologis tersebut tak dapat dicapai sekaligus tetapi berproses, setahap demi setahap.

Mengajar bukan sekedar menyampaikan materi, tetapi juga proses mengubah perilaku siswa sesuai tujuan yang diharapkan. Oleh sebab itu, dalam proses mengajar terdapat kegiatan membimbing siswa agar siswa berkembang sesuai dengan tugas-tugas perkembangannya. Guru perlu untuk menguasai pengetahuan bidang studinya agar dapat menyampaikan kepada siswa dengan sebaik-baiknya. Diluar itu, kalau perilaku belajar siswa tidak memadai atau gagal mencapai hasil yang diharapkan, maka kesalahan ditimpakan kepada siswa. Jadi, kegagalan dianggap semata-mata karena siswa sendiri yang kurang kemampuan, kurang motivasi, atau kurang persiapan.

Melatih keterampilan baik keterampilan intelektual maupun keterampilan motorik sehingga siswa dapat dan berani hidup dimasyarakat, Oleh karena itu, seorang guru perlu memiliki kemampuan merancang dan mengimplementasikan berbagai strategi pembelajaran yang dianggap cocok dengan minat dan bakat serta sesuai dengan taraf perkembangan siswa termasuk didalamnya memanfaatkan berbagai sumber dan media pembelajaran untuk menjamin efektivitas pembelajaran.

Demikian halnya dengan guru sebagai tenaga pendidik guru dituntut memiliki inovasi dalam penyampaian materi pelajaran kepada siswa. Hal ini mendorong pemerintah untuk terus berupaya meningkatkan profesionalitas tenaga pendidik melalui pengadaan workshop, diklat, uji kompetensi guru, dan sertifikasi guru. Mengingat variasi cara mengajar guru berikut penggunaan media pembelajaran yang menarik dan tepat tentunya akan menjadi dorongan semangat bagi siswa dalam belajar maupun mengembangkan kompetensinya sehingga prestasi belajar dapat meningkat. [1]

Demikian dalam proses pembelajaran guru memegang peranan yang sangat penting, guru tidak hanya berperan sebagai model atau teladan bagi siswa yang diajarnya, tetapi juga sebagai pengelola pembelajaran[2]. Sehingga dengan demikian efektivitas proses pembelajaran terletak dipundak guru oleh karena itu, keberhasilan suatu proses pembelajaran sangat ditentukan oleh kualitas atau kemampuan guru. 
Rasa takut terhadap pelajaran matematika seringkali menghinggapi perasaan siswa di Sekolah Dasar. Oleh karena dalam hal ini peneliti akan melakukan penelitian mengenai faktor apa saja yang membuat siswa merasa sulit terhadap pembelajaran matematika. Sehingga nantinya diharapkan hasil penelitian ini dapat mengurangi kesulitan belajar matematika di kelas III, sehingga kesulitan belajar tersebut tidak berlanjut di kelas selanjutnya.

Dari uraian di atas maka peneliti ingin melakukan penelitian tentang Analisis Faktor Kesulitan Belajar Matematika Siswa Kelas III Pada Materi Mengenal Pecahan SDN 007 Palaran Tahun Ajaran 2017-2018.

\section{Metode}

Jenis penelitian ini adalah penelitian kualitatif, dalam penelitian ini menggunakan pendekatan deskriptif. Penelitian kualitatif [3] merupakan penelitian dengan menggunakan pendekatan naturalistik untuk mencari dan menemukan pengertian atau pemahaman tentang suatu fenomena dalam suatu latar berkonteks khusus yang dialami subjek peneliti misalnya perilaku persepsi, motivasi secara holistik dan dengan cara deskripsi dalam bentuk kata-kata dan bahasa pada suatu konteks yang alamiah

Penelitian deskriptif cocok untuk digunakan dalam penelitian ini, karena sesuai dengan maksud dan tujuan dari penelitian, yaitu untuk memperoleh gambaran tentang kesulitan-kesulitan belajar yang dihadapi siswa kelas III SDN 007 Palaran

Subyek dalam penelitian ini adalah siswa kelas III SD Negeri 007 Palaran yang berjumlah 22 orang, yang terdiri atas 12 perempuan dan 10 laki-laki. Pelaksanaan kegiatan di SD Negeri 007 Jl. Teratai RT 11 Simpang pasir Blok B Palaran

Dalam penelitian kualitatif instrumen penelitian adalah peneliti itu sendiri. Adapun teknik pengumpulan data melalui observasi, wawancara dan dokumentasi. Teknik analisis data yang digunakan yakni ada tiga tahapan. Pertama adalah reduksi data, tahap kedua penyajian data dan tahap ketiag yakn penarikan kesimpulan.[4]

\section{Hasil dan Pembahasan}

Berdasarkan hasil penelitian di SDN 007 Palaran ditemukan ada empat faktor yang menjadi penyebab kesulitan belajar siswa dalam pembelajaran matematika yakni guru, sarana prasarana, lingkungan keluarga dan kurikulum. Peranan guru terutama berkaitan dengan kemampuannya dalam menjelaskan dan memaparkan materi matematika dan sarana prasarana memiliki peran yang penting yang memberikan pengaruh terhadap kemampuan siswa dalam memahami pembelajaran matematika. Berikut akan dijelaskan masing masing analisis terhadap faktor kesulitan belajar matematika siswa.

\section{Guru}

Berdasarkan hasil observasi pada saat proses belajar mengajar berlangsung dan wawancara kepada beberapa orang siswa, guru kelas III SDN 007 Palaran telah menggunakan metode yang bervariasi namun penyampaian guru masih kurang dapat dipahami oleh beberapa siswa. Faktor penyebab adalah karena beberapa hal berikut yakni dari hasil wawancara dengan 22 orang siswa, 12 siswa mengatakan tersebut memang tidak menyukai pembelajaran matematika artinya minat terhadap pembelajaran matematika masih kurang. Faktor yang lain yakni 4 orang siswa mengatakan kurang paham hal ini karena materi matematika sifatnya berlanjut dari kelas 1, 2 dan 3, jika siswa kurang memahami materi kelas 1 dan 2 maka akan menyebabkan kesulitan di kelas 3. Selain itu, peneliti melakukan wawancara dengan 6 siswa lainnya didapatkan informasi bahwa guru jarang menggunakan media yang kongkret dalam pembelajaran. Padahal penggunaan media ini memiliki peran juga dalam mempermudah penyajian materi [5] 
Penggunaan metode yang bervariasi tanpa diikuti dengan penggunaan media yang beragam ternyata berdampak juga terhadap kesulitan pemahamam pembelajaran. Siswa merasa dirinya terlibat aktif jika guru melibatkan siswa dalam proses pembelajaran, seperti siswa membawa peralatan atau media yang menunjang keberhasilan proses pembelajaran, siswa secara otomatis akan lebih aktif mengikuti pelajaran karena keterlibatannya membawa benda-benda yang baru atau unik. Hal tersebut yang membuat siswa antusias mempraktikkan kembali di rumah apa yang guru mereka jelaskan pada saat di sekolah. [6]

Dengan demikian kesulitan yang dialami oleh siswa pada saat pembelajaran Matematika di pengaruhi oleh cara guru dalam menyampaikan materi pembelajaran, minat belajar siswa terhadap pembelajaran matematika, pemahaman siswa terhadap materi matematika di kelas yang sebelumnya dan variasi penggunaan media yang kurang.

\section{Sarana dan Prasarana}

Berdasarkan hasil observasi sekolah memiliki fasilitas yang lengkap dan jumlah ruang kelas yang memadai. Sarana dan prasarana di SDN 007 palaran mendukung pembelajaran matematika, Kondisi kelas dapat dikatakan baik, bangunan gedung adalah bangunan permanen yang aman untuk digunakan untuk belajar. Setiap kelas memiliki jendela dan ventilasi sebagai keluar masuk udara sehingga ruang kelas tidak pengap. Selain itu ruang kelas dilengkapi dengan kipas angin yang mendukung kenyamanan siswa dalam pembelajaran matematika. Tepat di depan tiap-tiap kelas memiliki wastafel yang berguna untuk mencuci tangan siswa, sehingga siswa tidak berjauh-jauh mencuci tangan di kamar kecil.

Sarana dan prasarana sekolah tersebut juga sudah dapat dikatakan baik, karena tiap kelas ada terdapat perpustakaan mini yang dapat digunakan siswa untuk membaca pada saat jam istirahat jam kosong atau guru-guru sedang rapat. Hal tersebut yang membuat orang tua senang karena anak mereka dibiasakan mandiri. Sarana dan prasarana di sekolah tersebut juga memiliki satu ruang kesenian, dimana siswa bisa menuangkan bakat nya di dalam ruangan tersebut. Sebagai contoh siswa kelas V mengikuti lomba puisi, mereka pun belajar di dalam ruangan tersebut. Agar siswa lebih fokus untuk berlatih. [7]

Berdasarkan hasil observasi kondisi yang kurang mendukung untuk pembelajaran Matematika adalah tata letak kelas yang tepat berada di depan lapangan bola, sehingga siswa kurang berkonsentrasi saat belajar karena melihat siswa lain sedang berolahraga. Pada saat pembelajaran sudah ada upaya yang dilakukan oleh guru yakni dengan menutup pintu kelas dan bersuara sedikit lebih nyaring agar konsentrasi siswa tidak terganggu namun ternyata upaya ini masih belum maksimal membuat siswa konsentrasi.

Konsentrasi merupakan kunci kekuatan dari proses pembelajaran, hal ini sesuai dengan teori Dimyati \& Mudjiono[8] yang menyatakan bahwa konsentrasi belajar siswa merupakan kemampuan memusatkan perhatian pada pelajaran. Konsentrasi sering kali terfokus karena beberapa hal, seperti tingkat kecerdasan rendah, kesehatan terganggu, dan tidak menguasai cara-cara belajar yang baik. Dalam hal ini disimpulkan bahwa keadaan kelas yang bertepatan dengan lapangan sekolah membuat siswa kurang konsentrasi dalam belajar, sehingga siswa kesulitan dalam memahami apa yang guru sampaikan karena konsentrasi terbagi oleh melihat teman sedang bermain di lapangan.

Dengan demikian kesulitan siswa dalam pembelajaran matematika disebabkan kondisi letak kelas yang kurang tepat sehingga berisik dang mengganggu konsentrasi serta pemahaman terhadap apa yang dijelaskan oleh guru saat pembelajaran berlangsung.

\section{Lingkungan Keluarga}

Keluarga merupakan pusat pendidikan yang pertama bagi siswa. Bimbingan orang tua serta perhatian dari orang tua menjadi faktor penting dalam keberhasilan belajar siswa. Hubungan yang baik antara orang tua dan siswa dibangun agar orang tua senantiasa mengerti kebutuhan dan kesulitan yang dialami oleh siswa. Hubungan yang baik dibangun dengan 
komunikasi dan meluangkan waktu serta mendampingi siswa belajar. selain itu orang tua perlu berkomunikasi secara teratur dengan guru tentang perkembangan belajar anaknya di sekolah sehingga kesulitan belajar siswa dapat diatasi. [9]

Berdasarkan hasil observasi peneliti melihat perhatian yang diberikan oleh orang tua kepada siswa seperti menunggu siswa pulang di taman sekolah dan menjemput anak setelah pulang sekolah. Perhatian kecil seperti ini termasuk dalam faktor eksternal peserta didik. Perhatian yang lain yakni mengantarkan anak untuk mengikuti les tambahan bahkan menunggu berjam jam untuk menjemput anaknya.

Berdasarkan hasil wawancara dengan siswa peneliti juga mendapatkan informasi bahwa dari 12 orang siswa yang diwawancara mengikuti les tambahan matematika di luar jam sekolah dan sisanya 10 orang belajar matematika bersama orang tua atau kakaknya di rumah. Hal ini menunjukkan bahwa orang tua siswa sangat antusias dan perhatian akan kemajuan anaknya khususnya dalam pemahaman terhadap pembelajaran matematika. Dengan demikian dapat disimpulkan bahwa faktor keluarga memiliki peran yang cukup penting terhadap kesulitan belajar yang yang dialami oleh anak.

\section{Kurikulum}

Kurikulum merupakan kunci utama dalam pelaksanaan pendidikan, dan juga sebagai pedoman bagi guru. Pembelajaran tidak hanya meliputi proses saja, tetapi terdapat juga perencanaan, proses, dan evaluasi. Persiapan materi, yaitu menyiapkan materi yang akan diajarkan Mempersiapkan media atau sember ajar, yaitu menyiapkan media dan sumber ajar yang akan dibutuhkan

Bersarkan hasil observasi perencanaan yang dilakukan oleh guru sebelum mengajar yakni membuat RPP yang disesuaikan dengan silabus yang ada, Sekolah tidak menyusun silabus sendiri melainkan sudah dikembangkan di tingkat nasional. Penyusunan RPP dilakukan secara mandiri oleh setiap guru, RPP dibuat pada setiap awal semester sebelum pembelajaran berlangsung.

Kurikulum 2013 yaitu kurikulum berbasis kompetensi yang merupakan konsep kurikulum yang menitik beratkan pada pengembangan karakter dan kemampuan melakukan kompetensi, tugas-tugas dengan ketentuan standar tertentu, sehingga hasilnya dapat dirasakan oleh siswa, seperti penguasaan terhadap kompetensi, materi tertentu. Tidak hanya berbasis pada kompetensi, hal penting dalam penerapan kurikulum 2013 adalah pendidikan karakter.

Kurikulum tingkat satuan pendidikan (KTSP) yaitu kurikulum yang menekankan pada keaktifan guru dalam proses pembelajaran, Kurikulum tingkat satuan pendidikan (KTSP) merupakan penyempurnaan dari kurikulum 2004 atau lebih dikenal dengan Kurikulum Berbasis Kompetensi (KBK). SDN 007 Palaran menggunakan kurikulum 2013 untuk kelas 1,2,4 sedangkan kelas 3,5 dan 6 masih menggunakan kurikulum tingkat satuan pendidikan (KTSP). Sedangkan kelas yang peneliti teliti masih menggunakan KTSP.

Berdasarkan hasil observasi tahap proses pembelajaran kegiatan awal yakni guru mengabsen dan memberi motivasi kepada siswa. Kegiatan inti. Proses pembelajaran guna mencapai tujuan yang dilakukan secara interaktif. Pada setiap kegiatan penutup, guru mengakhiri pembelajaran dengan efektif yaitu melakukan refleksi atau merangkum pelajaran dengan siswa.

Berdasarkan hasil observasi ini upaya guru yang dilakukan untuk mengurangi kesulitan belajar siswa yaitu memotivasi siswa untuk belajar lebih aktif lagi. Hal ini menunjukkan bahwa guru adalah penentu keberhasilan belajar mengajar antara lain ditentukan oleh kemampuan professional dan pribadi guru. Seperti yang dikatakan oleh Abdurahman[10]dalam bukunya bahwa dinamika ini menuntut guru selalu meningkatkan dan menyesuaikan kompetensinya agar mampu mengembangkan dan menyajikan materi 
pelajaran yang aktual dengan menggunakan berbagai pendekatan, metode, dan teknologi pembelajaran terkini.

Dengan demikian faktor kurikulum bukan menjadi faktor penyebab kesulitan belajar siswa dalam pembelajaram matematika.

\section{KESIMPULAN}

Berdasarkan hasil penelitian dan pembahasan analisis faktor penyebab kesulitan belajar matematika kelas III di SDN 007 Palaran kel. Simpang Pasir Kec. Palaran diperoleh kesimpulan sebagai berikut:

1. Guru memiliki peranan yang penting dalam mengatasi kesulitan belajar siswa. Berdasarkan hasil penelitian ini dapat diindentifikasiakn bahwa kesulitan belajar siswa disebabkan oleh beberapa hal berikut yakni kesulitan dalam memahami apa yang disampaikan oleh guru, kurangnya minat terhadap pembelajaran matematika dan kurang memahami matematika pada materi yang sebelumnya.

2. Sarana dan prasarana di sekolah telah mendukung proses pembelajaran Matematika. Kondisi kelas dapat dikatakan baik, bangunan gedung adalah bangunan permanen yang aman untuk digunakan untuk belajar, namun letak kelas yang berada di depan lapangan bola juga dapat menganggu konsentrasi belajar siswa. Siswa yang tidak konsentrasi akan kesulitan juga untuk memahami materi yang dijelaskan oleh guru

3. Lingkungan keluarga peserta didik baik itu ayah, ibu, dan saudara sudah cukup dikatakan membantu, jika orang tua tidak memahami peserta didik diberikan guru les privat untuk membantu kesulitan siswa.

4. Kurikulum bukan faktor penyebab utama dari penyebab kesulitan belajar siswa. Penggunaan kurikulum KTSP di kelas III SDN 007 Palaran berjalan sesuai pedoman akademik yang ada di sekolah.

\section{Daftar Pustaka}

[1] E. H. Hanifah, . "Identifikasi kesalahan siswa dalam menyelesaikan soal Cerita Matematika materi Sistem Persamaan Linier Dua Variabel berdasarkan metode analisis kesalahan Newman: studi kasus SMP Bina Bangsa Surabaya," Diss IAIN Sunan Ampel Surabaya, 2011.

[2] A. A. W. Tias and D. U. Wutsqa, "Analisis kesulitan siswa SMA dalam pemecahan masalah matematika kelas XII IPA di Kota Yogyakarta,” J. Ris. Pendidik. Mat., 2015.

[3] Sugiyono, Metode Penelitian Pendidikan Pendekatan Kuantitatif,Kualitatif, dan R\&D. Bandung: Cv Alfabeta, 2016.

[4] L. . Moleong, Metodologi Penelitian Kualitatif. Bandung: Remaja Rosdakarya, 2010.

[5] K. Nisa, "Analisis kesulitan belajar matematika pada peserta didik kelas VIII semester II pokok bahasan panjang garis singgung persekutuan dua lingkaran MTs Negeri Bonang tahun pelajaran 2010/2011," PhD diss., IAIN Walisongo, 2011.

[6] Kusumabangsa and A. Dhian, "Identifikasi Kesulitan Belajar Siswa Kelas V SD Negeri Sosrowijayan Kota Yogyakarta,” Basic Educ., 2016.

[7] E. Untari, "Diagnosis kesulitan belajar pokok bahasan pecahan pada siswa kelas V sekolah dasar," J. Ilm. STKIP PGRI Ngawi, 2013.

[8] Sugihartono, Psikologi Pendidikan. Yogyakarta: UNY Press, 2007.

[9] E. Wardani, "Analisis Faktor Eksternal kesulitan belajar matematika peserta didik kelas V MI Wahid Hasyim Tahun Akademik 2015/2016."

[10] M. Abdurrahman, Pendidikan Bagi Anak Berkesulitan Belajar. Jakarta: Rineka Cipta, 2012. 